\title{
Fallacious electrocardiographic interpretation in acute myocardial infarction
}

\author{
Rajiv Ananthakrishna, Prasanna Y Katti, Manjunath C Nanjappa \\ Cardiology Department, Sri Jayadeva Institute of Cardiovascular Sciences and Research, Bangalore, Karnataka, India
}

Correspondence to Dr Rajiv Ananthakrishna, rajiva.ms@gmail.com

\section{DESCRIPTION}

A 47-year-old male, with risk factors of diabetes mellitus and hypertension, had history of typical anginal chest pain of $8 \mathrm{~h}$ duration. A diagnosis of acute inferior wall and old anterior wall myocardial infarction was considered based on an ECG (figure 1A), and referred for further management. At admission, patient was asymptomatic and haemodynamically stable (Killip class I). There was no pericardial rub. The ECG was reanalysed. In addition to conspicuous ST segment elevation in inferior and precordial leads, an isoelectric baseline in lead I and abnormal P wave orientation in limb leads were appreciated (figure 1A). Limb lead reversal was suspected and an ECG was repeated. The infarct was confined to the anterior wall, with no evidence of inferior wall infarction (figure 1B). In the first ECG, the right arm electrode was interchanged with left foot, and left arm electrode was interchanged with right foot. Hence, the reciprocal ST depression in limb leads manifest as ST elevation, simulating acute inferior wall infarction. This is likely to result in erroneous localisation of culprit vessel. Hence, it is imperative to adhere to the standard recommendations while recording an ECG. To conclude, one should be mindful of lead reversal and a systematic approach is prerequisite for accurate interpretation of an ECG.

\section{Competing interests None.}

Patient consent Obtained.
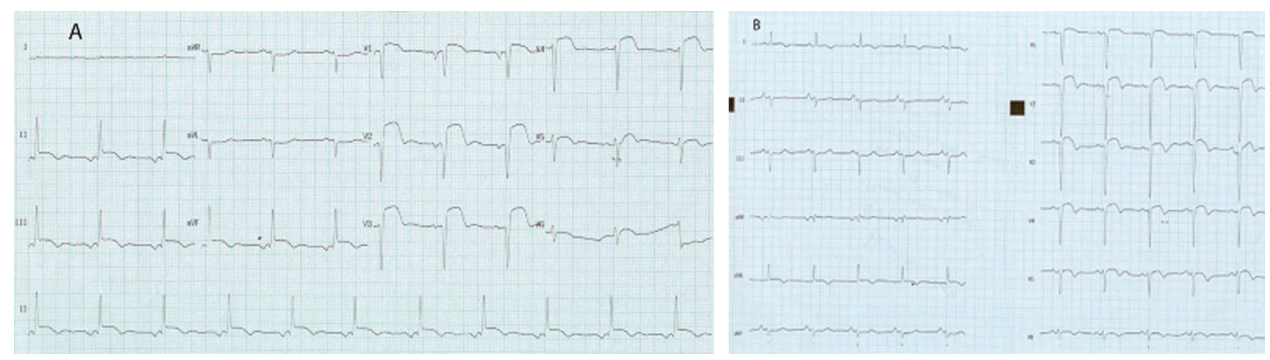

Figure 1 (A) ECG illustrating ST segment elevation in inferior and precordial leads. Additional findings include an isoelectric baseline in lead I, abnormal orientation of $\mathrm{P}$ waves in limb leads, pathological $\mathrm{Q}$ waves in V1 to V3 and poor $\mathrm{R}$ wave progression. (B) Repeat ECG demonstrating evidence of anterior wall myocardial infarction. There is no evidence of inferior wall infarction and $\mathrm{P}$ wave axis is normal.

This pdf has been created automatically from the final edited text and images.

Copyright 2012 BMJ Publishing Group. All rights reserved. For permission to reuse any of this content visit http://group.bmj.com/group/rights-licensing/permissions.

BMJ Case Report Fellows may re-use this article for personal use and teaching without any further permission.

Please cite this article as follows (you will need to access the article online to obtain the date of publication).

Ananthakrishna R, Katti PY, Nanjappa MC. Fallacious electrocardiographic interpretation in acute myocardial infarction. BMJ Case Reports 2012; 10.1136/bcr.11.2011.5228, Published XXX

Become a Fellow of BMJ Case Reports today and you can:

- Submit as many cases as you like

- Enjoy fast sympathetic peer review and rapid publication of accepted articles

- Access all the published articles

- Re-use any of the published material for personal use and teaching without further permission

For information on Institutional Fellowships contact consortiasales@bmjgroup.com

Visit casereports.bmj.com for more articles like this and to become a Fellow

Keep up to date with all published cases by signing up for an alert (all we need is your email address) http://casereports.bmj.com/cgi/alerts/etoc 